\title{
UPAYA MENINGKATKAN HASIL BELAJAR MATEMATIKA DENGAN METODE RESITASI PADA MATERI BANGUN DATAR SISWA KELAS VII SMP TEKNOLOGI PILAR BANGSA TANGERANG
}

\author{
Yupiter Carlis Gulo
}

SMPN 2 Sepatan

\section{INFO ARTICLES}

\section{Article History:}

Received: 08-12-2018

Revised: $12-12-2018$

Approved: 25-12-2018

Publish Online: 30-12-2018

Key Words:

resitasi method, the results of learning mathematics

under a Creative Commons AttributionShareAlike 4.0 International License.

\begin{abstract}
This research aims to improve the teaching and learning process and improve the results of learning math on the material flat-wake up with the method resitasi of Class VII JUNIOR HIGH Technology nation's pillars of Tangerang. This type of research is qualitative research i.e. Research action class (PTK), the learning model used was the model MC Tanggart and Kemmis. The application of this method is done in the III cycle. Cycle I gained an average rating of 57 students. cycle II obtained an average score of 65 students. Cycle III average student gained 81. A summary of this research is to study with the method resitasi was able to improve the results of student learning and fun for students.
\end{abstract}

\begin{abstract}
Abstrak: Penelitian ini bertujuan memperbaiki proses belajar mengajar dan meningkatkan hasil belajar matematika pada materi bangun datar dengan metode resitasi kelas VII SMP Teknologi Pilar Bangsa Tangerang. Jenis penelitian ini adalah penelitian kualitatif yaitu penelitian tindakan kelas (PTK), model pembelajaran yang digunakan adalah model MC Tanggart dan Kemmis.. Penerapan metode ini dilakukan dalam III siklus. Siklus I diperoleh nilai ratarata siswa 57. siklus II diperoleh nilai rata-rata siswa 65. Pada siklus III nilai rata-rata siswa yang diperoleh 81. Simpulan dari penelitian ini adalah pembelajaran dengan metode resitasi mampu meningkatkan hasil belajar siswa dan menyenangkan bagi siswa.
\end{abstract}

Correspondence Address: Pd. Jaya, Sepatan, Tangerang, Banten 15520; e-mail: piterepsol@gmail.com

How to Cite (APA $6^{\text {th }}$ Style): Gulo, Y.C.. (2018). Upaya Meningkatkan Hasil Belajar Matematika dengan Metode Resitasi pada Materi Bangun Datar Siswa Kelas VII SMP Teknologi Pilar Bangsa Tangerang. JKPM (Jurnal Kajian Pendidikan Matematika), Vol 4(1), 53-60

Copyright: Gulo, Y.C. (2018)

Competing Interests Disclosures: The authors declare that they have no significant competing financial, professional or personal interests that might have influenced the performance or presentation of the work described in this manuscript. 


\section{PENDAHULUAN}

Pendidikan merupakan suatu hal yang sangat penting bagi setiap orang, karena pendidikan salah satu cara untuk mendorong seseorang untuk maju dan berkembang. Walaupun pendidikan selalu mengalami perubahan dan perkembangan dalam kehidupan seorang individu yang dapat mempengaruhi seluruh aspek sikap dan kepribadiannya. Dalam buku Hayat \& Yusuf (2010, h. 9), "hasil studi menunjukkan bahwa diantara 38 negara, prestasi siswa SMP Indonesia berada pada urutan 32-IPA dan 34-Matematika". Sementara perolehan nilai matematika pada ujian nasional, untuk semua tingkat dan jenjang pendidikan selalu pada angka yang yang rendah. Melihat keadaan yang seperti ini perlu dilakukan perbaikan proses pembelajaran yang berkaitan dengan metode pembelajaran di kelas.

Salah satu proses pendidikan yang dilakukan oleh setiap orang yaitu pendidikan di sekolah yang secara keseluruhan dapat diwujudkan dalam kegiatan belajar mengajar. Berdasarkan hasil belajar matematika yang rendah tersebutmenjadi masalah yang sangat serius untuk diperhatikan. Proses pembelajaran dan metode pembelajaran salah satu kunci untuk menentukan peningkatan hasil belajar. Penggunaan metode mengajar yang tepat, merupakan suatu alternatif mengatasi masalah rendahnya daya serap siswa terhadap pelajaran matematika, guna meningkatkan mutu pengajaran. Penerapan suatu metode pengajaran harus ditinjau dari segi keefektifan, keefesienan dan kecocokannya dengan karakteristik materi pelajaran serta keadaan siswa yang meliputi kemampuan, kecepatan belajar, minat, waktu yang dimiliki dan keadaan sosial ekonomi siswa sebagai obyek. Hal ini sesuai dengan pernyataan Syaiful Bahri Djamarah bahwa "seorang guru tidak melaksanakan tugasnya bila dia tidak menguasai satu pun metode mengajar yang di rumuskan", (Djamarah \& Aswan, 2010:46).

Berdasarkan observasi penelitian di SMP Teknologi Pilar Bangsa terdapat masalah yang sangat serius yaitu rendahnya hasil belajar matematika siswa, ini dibuktikan dengan hasil wawancara dengan guru bidang studi matematika dan juga hasil ulangan siswa yang mayoritas di bawah KKM yang di tetapkan di sekolah. Dari 30 siswa, hanya 13 siswa yang memenuhi standar KKM, sedangkan 15 siswa lainnyaberada di bawah KKM yang ditetapkan sekolah. Dengan keadaan seperti ini harus segera di atasi dan dicari pemecahan masalahnya dalam meningkatkan hasil belajarnya.

Rendahnya prestasi matematika siswa kelas VII di SMP Teknologi Pilar Bangsa, disebabkan kurangnya latihan atau pemberian tugas yang dilakukan oleh guru, hal tersebut diakibatkan oleh keterbatasan waktu yang tersedia, tidak adanya evalusi di akhir pembelajaran, media belajar yang tidak di gunakan oleh guru dalam pembelajaran, karena sarana dan prasarana disekolah yang belum memadai, metode pembelajaran yang belum bervariasidan juga adanya kegiatan penambahan ruangan sekolah yang mengharuskan anak sering belajar tidak dalam ruangan tetapi proses pembelajaran dilaksanakan di luar ruangan,sehingga proses belajar mengajar kurang efektif dan efisien.

Dengan keadaan tesebut, dibutuhkan sebuah tindakan yang dapat mengatasi keadaan tersebut.Salah satu cara mengatasi hal tersebut dengan menerapkan metode pembelajaran yang relevan yang dapat mengatasi masalah tersebut. Peneliti mencoba menerapkan metode pembelajaran resitasi (penugasan) yaitu metode penyajian bahan dimana guru memberikan tugas tertentu agar siswa melakukan kegiatan belajar (Djamarah \& Aswan, 2010: 85). Hasil belajar merupakan kemampuan siswa dalam memenuhi sebuah atau sejumlah tahapan pencapaian pengalaman belajar dalam suatu kompetensi dasar. Pekerjaan rumah (PR) dalam bahasa inggris home work tidak sama dengan dengan metode resitasi. Pekerjaan rumah biasanya siswa hanya mengerjakan dan tidak mempertanggungjawabkan jawabannya sehingga jawaban yang mereka dapat belum tentu di kerjakan sendiri. Tetapi penugasan pada metode resitasi siswa memiliki beban yang 
mengharuskan mereka untuk belajar karena mereka harus mampu mempertanggungjawabkan di depan kelas baik secara lisan maupun tulisan dan juga melatih mental siswa untuk lebih aktif dalam proses pembelajaran.

Berdasarkan pernyataan di atas, maka akan di lakukan penelitian tindakan kelas dengan judul "Upaya Meningkatkan Hasil Belajar Matematika dengan Metode Resitasi pada Materi Bangun Datar Siswa Kelas VII SMP Teknologi Pilar BangsaTangerang”. Adapun metode penelitian tindakan kelas yang akan digunakan dalam menyelesaikan masalah tersebut adalah menggunakan teori model pembelajaran Kemmis dan MC Tanggar.

Penelitian ini bertujuan memperbaiki proses belajar mengajar dan meningkatkan hasil belajar matematika pada materi bangun datar dengan metode resitasi kelas VII SMP Teknologi Pilar Bangsa Tangerang.

\section{METODE}

Jenis penelitian ini adalah Penelitian tindakan kelas menggunakan metode resitasi yaitu metode pemberian tugas oleh guru kepada siswa dimana siswa mengerjakan dan mempertanggungjawabkannya. model pembelajaran yang di gunakan adalah model spiral Kemmis dan MC Tanggart (1988), penelitian tindakan pada hakikatnya berupa rangkaian kegiatan yang terdiri atas empat langkah, yaitu perencanaan (Plan), tindakan (Act), pengamatan (Observe) dan refleksi (Reflect). Penelitian ini dilaksanakan dalam tiga siklus.

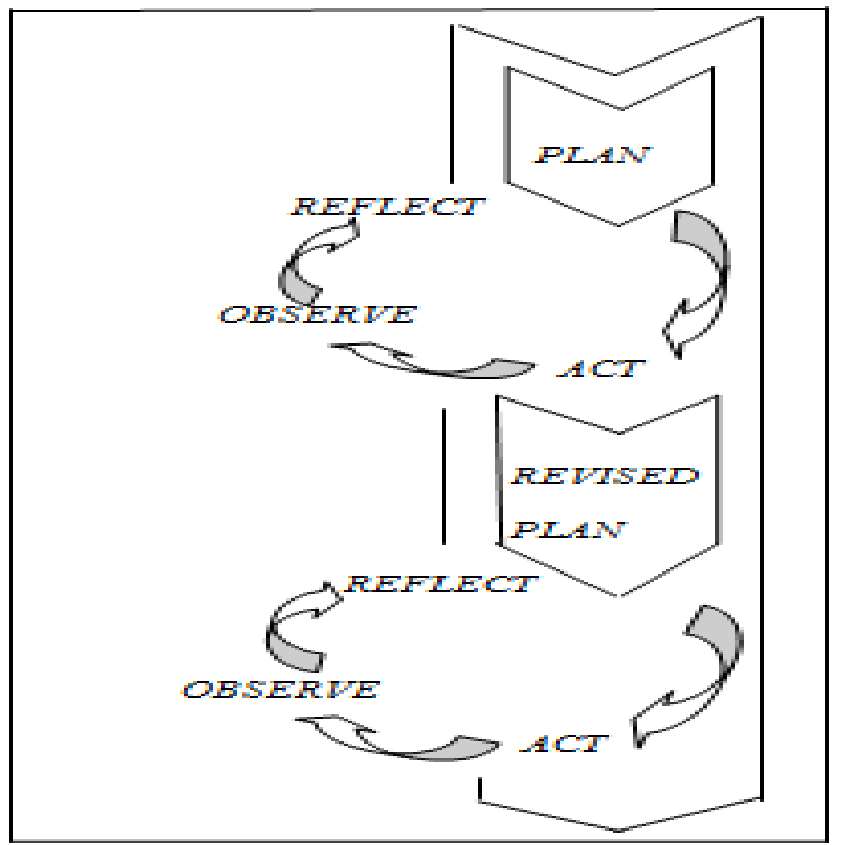

Gambar 1. Siklus PTK

Pada penelitian ini, peneliti melaksanakan pembelajaran dengan menerapkan salah satu metode pembelajaran yaitu metode resitasi yang bertujuan untuk meningkatkan prestasi belajar matematika siswa kelas VII-D SMP Teknologi Pilar Bangsa.Peran peneliti adalah sebagai perencana, pelaksana tindakan, dan pelaporan hasil penelitian. Adapun unsur-unsur yang telibat dalam penelitian ini adalah 2 orang guru matematika SMP Teknologi Pilar Bangsa yaitu Kadmarih, S.Pd dan Sumitro S.Pd yang berperan sebagai observer 
Untuk mengetahui sejauh mana efektivitas tindakan kelas ini dilakukan, maka diperlukan alat-alat pemantauan dan evaluasi yang terinci sehingga dapat digunakan sebagai alat ukur keberhasilan. Beberapa teknik pengumpulan data dalam penelitian tindakan ini sebagai berikut :

Tes tertulis : Tes tertulis merupakan data yang diperoleh dari soal yang dikerjakan siswa dan digunakan sebagai alat ukur untuk mengetahui sejauh mana peningkatan hasil belajar matematika siswa.

Wawancara : Wawancara merupakan data yang diperoleh dari hasil percakapan dengan guru bidang studi matematika terkait dengan kondisi siswa

Observasi : Observasi merupakan langkah awal dalam melakukan penelitian, ini bertujuan untuk mengetahui situasi sekolah dan juga situasi siswa yang akan diberikan tindakan.

Data yang diperoleh dari hasil penelitian tindakan kelas ini dianalisis secara kualitatif dan kuantitatif pada setiap siklus. Hasil dari analisis digunakan sebagai acuan untuk perbaikan kegiatan pembelajaran pada setiap siklus.

Analisis kualitatif data yang diperoleh dari hasil wawancara, lembar obsevasi akan dianalaisis secara kualitatif. Analisis wawancara dan lembar observasi dilakukan dengan mengambil kesimpulan dari data yang diperoleh.

Analisis Kuantitatif didapat dari Hasil belajar siswa pada pre-test dan post-test setiap siklus diberi nilai sesuai dengan penyekoran setiap butir soal pada masing-masing tes.Analisis kuantitatif dilakukan dalam bentuk perbandingan hasil belajar dari pre-test dan post-test setiap siklus yang berupa rata-rata hasil belajar.Jika rata-rata hasil belajar setiap siklus meningkat dikatakan upaya peningkatan hasil belajar dengan metode resitasi berhasil

Kriteria keberhasilan belajar siswa (sesuai dengan tujuan akhir dalam penelitian ini), yaitu :

Tingkat keberhasilan siswa :

$$
\begin{array}{ll}
>81 \% & =\text { sangat baik } \\
61 \%-80 \% & =\text { tinggi } \\
41 \%-60 \% & =\text { sedang } \\
21 \%-40 \% & =\text { rendah } \\
<20 \% & =\text { sangat rendah } \\
\text { Tingkat keaktifan siswa } \\
>81 \% & =\text { sangat baik } \\
61 \%-80 \% & =\text { tinggi } \\
41 \%-60 \% & =\text { sedang } \\
21 \%-40 \% & =\text { rendah } \\
<20 \% & =\text { sangat rendah }
\end{array}
$$

\section{HASIL}

\section{Hasil Siklus I}

Setelah melaksanakan pembelajaran dengan metode resitasi pada siklus I, hasil yang diperoleh menunjukkan adanya peningkatan hasil belajar meskipun rata-rata kelas masih berada di bawah KKM sekolah $(\mathrm{KKM}=72)$. Berikut hasil penelitian pada siklusI :

Siswa yang mendapat nilai $>\mathrm{KKM}=4$ orang

Siswa yang mendapat nilai $<\mathrm{KKM}=26$ orang

Nilai rata-rata kelas $=57$

Dari data diatas dibuat tabel yang diperoleh dari hasil belajar siklus I : 
Tabel 1. Hasil belajar Siklus I

\begin{tabular}{ccccc}
\hline Interval & $f_{i}$ & $x_{i}$ & $f_{i} x_{i}$ & persentase \\
\hline $20-29$ & 1 & 24,5 & 24,5 & $3,3 \%$ \\
$30-39$ & 1 & 34,5 & 34,5 & $3,3 \%$ \\
$40-49$ & 5 & 54,5 & 222,5 & $16,6 \%$ \\
$50-59$ & 7 & 54,5 & 381,5 & $23,3 \%$ \\
$60-69$ & 12 & 64,5 & 774 & $40 \%$ \\
$70-79$ & 4 & 74,5 & 298 & $13,3 \%$ \\
Jumlah & 30 & 307 & 1735 & $99,9 \%$ \\
\hline
\end{tabular}

Dari data di atas diketahui hanya 4 orang siswa yang mendapat nilai di ratas KKM $(\mathrm{kkm}=72)$ dari total 30 siswa dengan persentase adalah 13,3\%. Berikut nilai siklus I. Nilai rata-rata siswa pada pre-test adalah 2. Nilai rata-rata siswa pada post-test I adalah 57.

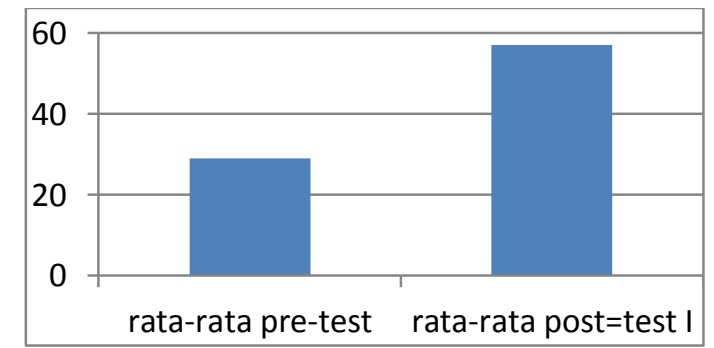

Gambar 2. Diagram 1 Hasil Belajar Siklus I

Dari gambar di atas menunjukkan adanya peningkatan hasil belajar pada siklus I walaupun terlihat masih banyak nilai siswa yang berada di bawah KKM sekolah. Dengan demikian evaluasi hasil belajar pada siklus I dikategori kurang baik, maka perlu dilakukan perbaikan tindakan dan pembelajaran dilanjutkan pada siklus II. Cara perhitungan tabel frekuensi dilampirkan pada bagian lampiran.

\section{Hasil Siklus II}

Setelah melaksanakan pembelajaran dengan metode resitasi pada siklus II maka siswa diberikan soal post-test II, hasil yang diperolah menunjukkan adanya peningkatan hasil belajar meskipun rata-rata masih berada dibawah KKM sekolah (KKM=72). Hasil belajar disajikan dalam bentuk table berikut :

Tabel 2. Hasil Belajar Siklus II

\begin{tabular}{ccccc}
\hline Interval & $f_{i}$ & $x_{i}$ & $f_{i} x_{i}$ & persentase \\
\hline $15-26$ & 1 & 20,5 & 20,5 & $3,4 \%$ \\
$27-38$ & 2 & 32,5 & 65 & $6,8 \%$ \\
$39-50$ & 4 & 44,5 & 178 & $13,4 \%$ \\
$51-62$ & 6 & 65,5 & 339 & $20 \%$ \\
$63-74$ & 3 & 68,5 & 205,5 & $10 \%$ \\
$75-86$ & 14 & 80,5 & 1127 & $46,8 \%$ \\
Jumlah & 30 & 307 & 1735 & $99,8 \%$ \\
\hline
\end{tabular}

Siswa yang mendapat nilai $>\mathrm{KKM}=14$ orang

Siswa yang mendapat nilai $<\mathrm{KKM}=16$ orang

Nilai rata-rata kelas $=65$

Dari data di atas, hasil belajar matematika pada siklus II, hanya 14 siswa yang mendapat nilai berada diatas KKM (72) dari total 30 siswa sehingga tingkat keberhasilan $=46,6 \%$ dengan nilai rata-rata $=65$. 
Tabel 3. Hasil Belajar Siklus I samapi Siklus II

\begin{tabular}{ccc}
\hline Nilai rata-rata pre-test & Nilai rata-rata post-test I & Nilai rata-rata post-test II \\
\hline 29 & 57 & 65 \\
\hline
\end{tabular}

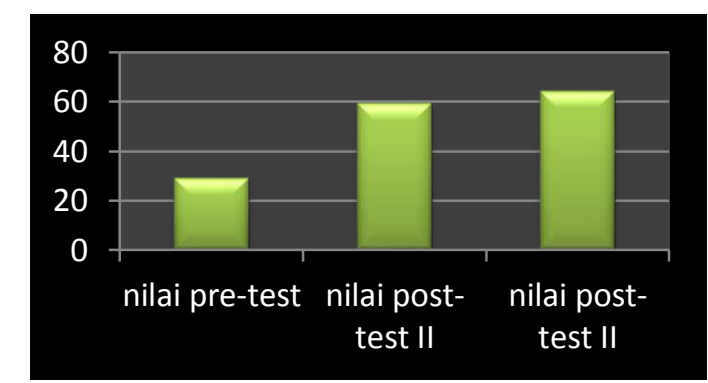

Gambar 3. Diagram 2 Hasil Belajar Siklus II

Dari hasil evaluasi belajar pada siklus II dapat dikatakan cukup, karena tingkat keberhasilan mencapai 46,6\% dengan nilai rata-rata (65). Namun demikian harus ada usaha untuk lebih meningkatkan hasil belajar siswa dengan pencapaian nilai diatas KKM melebihi 50\%, maka akan pembelajaran dilanjutkan pada siklus ke-III.

\section{Hasil Siklus III}

Setelah melaksanakan pembelajaran dengan metode resitasi pada siklus III maka siswa diberikan soal post-test, hasil yang diperoleh menunjukkan adanya peningkatan hasil belajar bahkan melebihi KKM yang ditetapkan disekolah. Berikut hasil belajar disajikan dalam tabel berikut :

Tabel 4. Hasil Belajar Siklus III

\begin{tabular}{ccccc}
\hline Interval & $f_{i}$ & $x_{i}$ & $f_{i} x_{i}$ & persentase \\
\hline $55-60$ & 2 & 57,5 & 115 & $6,6 \%$ \\
$61-66$ & 0 & 63,5 & 0 & $0 \%$ \\
$67-72$ & 2 & 59,5 & 139 & $6,6 \%$ \\
$73-78$ & 4 & 75,5 & 302 & $13,3 \%$ \\
$79-84$ & 6 & 81,5 & 489 & $20 \%$ \\
$85-90$ & 16 & 87,5 & 1400 & $53,3 \%$ \\
Jumlah & 30 & 435 & 2445 & $99,8 \%$ \\
\hline
\end{tabular}

Tabel 5. Hasil Belajar dari Siklus I Sampai Siklus III

\begin{tabular}{cccc}
\hline $\begin{array}{c}\text { Nilai rata-rata } \\
\text { pre-test }\end{array}$ & $\begin{array}{c}\text { Nilai rata-rata } \\
\text { post-test } \text { I }\end{array}$ & $\begin{array}{c}\text { Nilai rata-rata } \\
\text { post-test } \text { II }\end{array}$ & $\begin{array}{c}\text { Nilai rata-rata } \\
\text { post-test III }\end{array}$ \\
\hline 29 & 57 & 65 & 81 \\
\hline
\end{tabular}

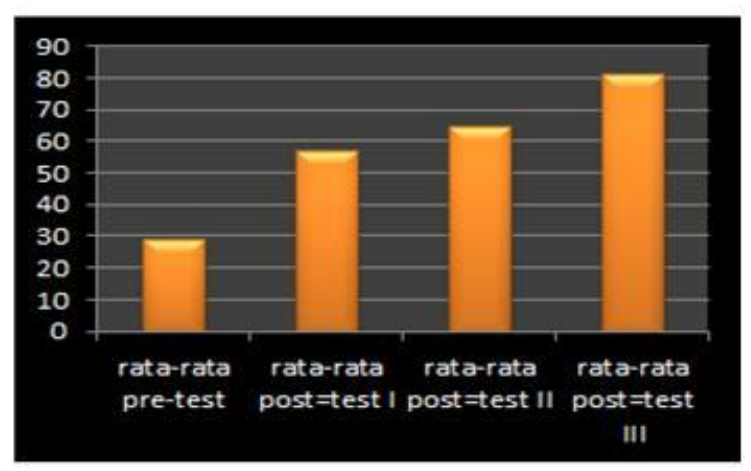

Gambar 4. Diagram 3 Hasil Siklus III 
Dari data di atas mununjukkan adanya peningkatan hasil belajar matematika siswa. Soal post-test yang diberikan kepada siswa mencakup seluruh materi pembelajaran yang dilakukan selama tindakan berlangsung. Berikut hasil belajar pada post-test:

Siswa yang mendapat nilai $>\mathrm{KKM}=26$ orang

Siswa yang mendapat nilai $<\mathrm{KKM}=4$ orang

Nilai rata-rata kelas $=81$

Dari hasil penelitian di atas, siswa yang mencapai nilai di atas KKM sekolah sebanyak 26 siswa dengan persentase $86,6 \%$ dapat dikatakan pembelajaran yang dilakukan dari siklus I dan pada isiklus III dikategorikan berhasil. Berdasarkan hasil belajar pada post-test yang dikategorikan berhasil, maka penelitian tindakan kelas ini tidak dilanjutkan pada siklus berikutnya.

\section{PEMBAHASAN}

Pada penelitian tindakan kelas yang dilaksanakan peneliti dengan judul "Upaya Meningkatkan Hasil Belajar Matematika dengan Metode Resitasi pada Materi Bangun Datar Siswa Kelas VII SMP Teknologi Pilar Bangsa Tangerang”. Berikut pembahasan tindakan setiap siklus :

\section{Siklus I}

Pada siklus I hasil pengamatan yang diperoleh dari hasil observasi terlihat masih banyak hal-hal yang harus di operbaiki oleh guru terutama dalam hal menciptakan kondisi kelas yang menyenangkan dan aktif. Hasil yang di dapat pada siklus I disajikan dalam bentuk diagram 11 Nilai rata-rata siswapada pre-test adalah 29. Nilai rata-rata siswapada post-test I adalah 57

\section{Siklus II}

Hasil pengamatan pada siklus ke-II, pembelajaran mulai terlihat aktif karena guru sudah mampu berinteraksi dengan siswa, guru sering menghampiri siswa dalam kelompok sehingga siswa tidak malu untuk bertanya jika ada materi yang kurang dipahami dan siswa tidak malu mempresentasikan hasil latihan yang mereka kerjakan dalam kelompok. ini ditandai dengan siswa dalam kelompok mampu mempresentasikan jawaban mereka dari soal LKS yang diberikan oleh guru. Akan tetapi karena tugas dalam bentuk kelompok, sebagian siswa kurang aktif dalam kelompok sehingga menimbulkan adanya ketidak kondusifan siswa dalam kelas. Siswa terlihat kurang kompak dalam kelompoknya, sebagian siswa membuat keributan seperti pindah tempat dikelompok lain, ngobrol dengan teman kelompok lain. Hasil yang didapat pada siklus I disajikan dalam bentuk diagram 2. Siswa yang mendapat nilai $>\mathrm{KKM}=14$ orang Siswa yang mendapat nilai $<\mathrm{KKM}=16$ orang. Nilai rata-rata kelas $=65$

\section{Siklus III}

Hasil observasi pada siklus ke-III, Guru membagi siswa dalam beberapa kelompok yaitu teman sebangkunya supaya siswa lebih nyaman dalam kelompoknya. Pembelajaran sudah terlihat aktif, interaksi siswa dengan guru terjalin dengan baik, siswa tidah malu untuk bertanya kepada guru dan tidak malu untuk mepresentasikan hasil jawabannya. Pembelajaran dengan metode resitasi terlaksana dengan baik, ini dapat dilihat pada saat siswa mengerjakn soal LKS, tanpa di tunjuk oleh guru siswa barebut untuk maju mengerjakan dan mempresentasikan hasil jawabannya di depan kelas. Hasil yang diperoleh pada siklus III disajikan dalam diagram 3. Siswa yang mendapat nilai $>\mathrm{KKM}=26$ orang. Siswa yang mendapat nilai < $\mathrm{KKM}=4$ orang. Nilai rata-rata kelas $=81$ 


\section{SIMPULAN}

Dari hasil penelitian dapat disimpulkan bahwa pembelajaran dengan metode resitasi mampu meningkatkan hasil belajar matematika siswa. Terjadi peningkatan hasil belajar matematika yang diperoleh dari proses belajar menggunakan metode reitasi. Hal ini ditunjukkan dengan peningkatan rata-rata tes seluruh siswa. Pada siklus I rata-rata nilai siswa kelas VII-D adalah 57 meningkat menjadi 65 pada siklus II, meningkat menjadi 78 pada siklus III dan pada hasil post-test secara keleluruhan menjadi 81. Pembelajaran dengan metode resitasi mempermudah siswa dalam menyelesaikan soal-soal matematika.

\section{DAFTAR RUJUKAN}

Djamarah, S.B dan Aswan. (2010). Strategi Belajar Mengajar. Jakarta: Dar-Ruzz 